Bangl. J. Vet. Med. (2010). 8 (2) : 149 - 155

\title{
STANDARDIZATION OF MULTIPLEX REVERSE TRANSCRIPTION-POLYMERASE CHAIN REACTION AND TYPING OF FOOT-AND-MOUTH DISEASE VIRUS PREVALENT IN BANGLADESH
}

\author{
M. A. Zinnah ${ }^{1,3}$, M. T. Islam ${ }^{1,2}$, M. M. Rahman ${ }^{1}$, M. T. Hossain ${ }^{1}$, M. A. Zinnah ${ }^{1}$, M. R. Bari ${ }^{4}$, \\ M. H. Haque ${ }^{1,5}$, M. S. R. Khan ${ }^{1}$ and M. A. Islam ${ }^{1 *}$
}

${ }^{1}$ Department of Microbiology and Hygiene, ${ }^{2}$ Department of Medicine, Faculty of Veterinary Science, Bangladesh Agricultural University, Mymensingh-2202, Bangladesh, ${ }^{3}$ Department of Microbiology and Hygiene, Faculty of Veterinary and Animal Science, Sylhet Agricultural University, Sylhet, Bangladesh, ${ }^{4}$ School of Agriculture and Rural Development, Bangladesh Open University, Gazipur-1705, Bangladesh, ${ }^{5}$ Department of Animal Husbandry and Veterinary Science, Rajshahi University, Rajshahi

"Corresponding author's e-mail: alim_bau@yahoo.co.in

\begin{abstract}
Foot-and-mouth disease (FMD) is a devastating viral disease of cattle that causes severe economic losses in terms of loss of production and calf mortality in Bangladesh. Despite of regular vaccination, outbreak of the disease has become a regular event throughout the country every year. Determination of prevailing serotypes of the causal agent foot-and-mouth disease virus (FMDV) is now crucial need for strategic vaccination programme. The present research work was aimed to standardize a multiplex RT-PCR assay typing of foot-and-mouth disease virus serotypes prevalent among cattle population of Bangladesh. Uniplex and multiplex RT-PCRs were successfully developed and standardized using the extracted RNA of reference FMDV (Type A, O and Asia 1) following adjustment of the concentration of the viral RNA of each serotype, volume of reaction mixture and thermal profile. The MPCR was evaluated on 82 field samples (vesicular fluid, tongue epithelium and tissue from inter-digital space) of the years 2007 and 2008. Of the 82 field samples, 56 (68.29\%) were found positive for FMDV. The mPCR successfully differentiated single as well as dual serotypes infection. The serotypes A, O and Asia 1 were confirmed in the samples of the year 2007 and only serotype $O$ in samples of the year 2008. Higher detection rate was found in vesicular fluid $(100 \%)$ followed by tongue epithelium $(79.66 \%)$. It may be concluded that the MRT-PCR standardized in this study could be used for detection and differentiation of FMDV serotypes using field samples.
\end{abstract}

Key words: Foot-and-mouth disease virus; serotypes; multiplex RT-PCR

\section{INTRODUCTION}

Foot-and-mouth disease (FMD) is an acute febrile, highly contagious viral disease of almost all the clovenhoofed domestic animals such as cattle, buffalo, sheep, goat and swine caused by a RNA virus, foot-and-mouth disease virus (FMDV). The FMDV also affects more than 70 species of wild animals including deer (Fenner et al., 1993). Infection with FMDV generally results by the rapid appearance of high rise of body temperature followed by formation of vesicles on the epithelia and skin, particularly on mouth, nose and inter-digital space of foot (Sahan, 1962; Bachrach, 1968). Even after recovery from acute infection, most animals act as a carrier for each serotype of the virus and the agent can be isolated from their esophagus and throat fluid after 2-3 years of post-infection (van Bekkum et al., 1959; Burrows, 1966; Auge de Mello et al., 1970). FMDV belongs to the genus Aphthovirus under the family Picornaviridae. FMDV is a non-enveloped, single stranded virus and possesses positive sense RNA genome of approximately 8,500 bases surrounded by four structural proteins (VP1 - 4) to form an icosahedral capsid (Rueckert, 1996). There are seven serotypes of FMDV, namely, O, A, C, SAT 1, SAT 2, SAT 3 and Asia 1 (OIE, 2009).

FMD is associated with high morbidity $(100 \%)$ and variable rate of mortality $(1-100 \%)$ depending on the age distribution of animals. In case of young animals, mortality rate may reach up to $100 \%$. It causes low productivity for the affected countries, severe restrictions are placed on international trade of animals and animal products (meat, milk, hide and butter) due to its transboundary nature of transmission (OIE, 2004). It is estimated that $25 \%$ productivity of individual recovered animals are lost due to FMD (Russel and Endington, 1985). 
FMD is one of the major constraints for livestock development in Bangladesh. Outbreak of this disease causes severe economic losses to the livestock industries in terms of loss of draft power, meat and milk production, infant and adult animal mortality. About 1.5 million US\$ economic losses is incurred per year only due to the outbreak of FMD in Bangladesh (BBS, 1999). Despite of regular vaccination, outbreak of this disease has become a regular event throughout the country every year. The frequent outbreak of the disease may be due to introduction of new mutant viruses which are the result of inappropriate serotypes used for vaccine preparation or importation of vaccines of heterologous strains from abroad. Moreover, a significant number of cattle and buffaloes have been entering from India to Bangladesh every year either through proper or improper channels which directly / indirectly serves as a source of new virus introduction. According to Islam et al. (2000), serotype $\mathrm{A}$ and $\mathrm{O}$ of FMDV were prevailing in this country. From the year 2000 until now, no systematic research was conducted to study the molecular epidemiology of the FMDV in Bangladesh. We do not have any recent database about the serotypes of FMDV currently circulating among the livestock population of Bangladesh.

In order to limit the spread of FMD in any outbreak area, a reliable and rapid, confirmatory diagnosis of the disease is a must. Specific determination of FMDV serotype circulating in an outbreak area is crucial for administration of emergency vaccines with appropriate antigen. In many developing countries, including Bangladesh, FMD is routinely diagnosed just by recording clinical signs and symptoms in field conditions. Clinical diagnosis of FMD is very difficult for sheep and goats, in which clinical signs are not manifested often by the affected animals (Callens et al., 1998). Furthermore, several other vesicular virus infections, including those caused by swine vesicular disease (SVD), vesicular stomatitis (VS) and rabies cannot be distinguished from FMDV infection just on the basis of clinical findings. To distinguish FMD from other virus diseases, confirmatory diagnosis either by serological or by molecular methods have no alternatives. Traditionally, laboratory diagnosis is achieved by enzyme-linked immunosorbent assay (ELISA) for the detection of specific FMDV antigens from epithelial tissue suspensions, often accompanied by concurrent isolation of virus in BHK21 cell (Ferris and Dawson, 1988; Ferris et al., 1988; Knowles and Samuel, 1998; Hamblin et al., 1984), complement fixation test, virus neutralization test, day-old mouse inoculation etc.

Among the molecular methods, RT-PCR has been using routinely in many countries as a highly sensitive, rapid and reliable means for typing of FMDV from the acute infection to the asymptomatic infection (Marquardt et al., 1995; Callens and De Clercq, 1997). So far literature available, there is no report of using either RT-PCR or MRT-PCR for typing of FMDV in Bangladesh. This paper describes the standardization of multiplex RT-PCR and typing of FMDV directly in the field samples.

\section{MATERIALS AND METHODS}

\section{Reference viruses}

The three different serotypes (A, O, Asia 1) of reference FMDV were obtained from the repository of the Department of Microbiology and Hygiene, Bangladesh Agricultural University, Mymensingh.

\section{Field samples}

A total of 82 samples (vesicular fluid, tongue epithelium and tissue from inter-digital space) were collected from suspected foot-and-mouth disease (FMD) affected cattle of different outbreak areas of five districts (Dhaka, Narshingdi, Rangpur, Comilla and Chittagong) of Bangladesh during the outbreak years 2007 and 2008. The samples were kept at $-86^{\circ} \mathrm{C}$ until used. The field samples (tongue epithelium, tissue from inter-digital space) were homogenized with sea sand using mortar and pestle and $20 \%$ suspensions were prepared by adding sterile phosphate buffered saline. The suspension was then centrifuged at $3000 \mathrm{rpm}$ for 10 min maintaining $4^{0} \mathrm{C}$ and supernatant was collected for extraction of viral RNA.

\section{Extraction of viral RNA}

The genomic viral RNA was extracted from field samples by using QIAamp RNA mini kit (Hilden, Germany) according to the manufacturer's instructions. 
Typing of FMDV by multiplex RT-PCR

\section{Reverse transcription (RT)}

Initially, $4 \mu \mathrm{l}$ of template RNA and $100(0.5 \mu \mathrm{l})$ pmols of RT-primer (RH) were heated at $70^{\circ} \mathrm{C}$ for $10 \mathrm{~min}$ followed by snap cooling on ice. Then $15.5 \mu \mathrm{l}$ reaction mixture containing $4 \mu \mathrm{l}$ X RT buffer, $2 \mu 110 \mathrm{mM}$ dNTPs, $1 \mu 1$ prime RNase inhibitors, $0.2 \mu 1$ AMV-RT and $8.3 \mu 1$ of RNase free water was added to the PCR tube containing RNA of FMDV. The RT was carried out at $42^{\circ} \mathrm{C}$ for 1 hour in a thermocycler followed by heating at $95^{\circ} \mathrm{C}$ for $5 \mathrm{~min}$. RT products were cooled on ice and stored at $-20^{\circ} \mathrm{C}$ until use.

\section{Polymerase chain reaction}

For uniplex PCR of each serotype of FMDV, the basic PCR reaction mixture $(50 \mu 1)$ contained $2 \mu 1$ of RT product, $5 \mu 1$ of 10X PCR buffer (LA buffer, Takara, Japan), $2 \mu 1$ of $25 \mathrm{mM} \mathrm{MgCl}_{2}, 2 \mu 1$ of $10 \mathrm{mM}$ dNTP, 100 pmols $(0.8 \mu \mathrm{l})$ each of virus specific and serotype specific primers (Table 1), $0.2 \mu 1$ of LA Taq DNA polymerase, $38 \mu \mathrm{l}$ of RNase free water. It was subjected to following thermal cyclic conditions: one cycle at $95^{\circ} \mathrm{C}$ for $15 \mathrm{~min}$, 30 cycles each at $95^{\circ} \mathrm{C}$ for $30 \mathrm{~s}, 55^{\circ} \mathrm{C}$ for $30 \mathrm{~s}$, and $72^{\circ} \mathrm{C}$ for $1 \mathrm{~min}$ followed by one cycle at $72^{\circ} \mathrm{C}$ for $10 \mathrm{~min}$.

Table 1. List of primers ${ }^{*}$ used for RT-PCR and MRT-PCR for serotyping of FMDV

\begin{tabular}{lll}
\hline Serotypes of FMDV & Primers & Sequence (5'-3') \\
\hline A & DHP 15 & CAAC GGGACGARCAAGTACTC \\
O & DHP 13 & GTGACTGAACTGCTTTACCGCAT \\
Asia 1 & DHP 9 & GACCTGGAGGTYGCGCTTGT \\
Universal (Reverse sense) & pNK61 & GACATGTCCTCCTGCATCTG \\
\hline
\end{tabular}

*The primers were selected according to the published report of Giridharan et al. (2005).

For multiplex PCR, initially the reaction mixture and cyclic conditions were same as uniplex PCR. Standardization of multiplex PCR was done by varying reaction components and cyclic conditions one at a time. Multiplex PCR was performed on all the serotypes at unit incremental annealing temperatures from $56^{\circ} \mathrm{C}$ to $70^{\circ} \mathrm{C}$ and then at $72^{\circ} \mathrm{C}$ to $74^{\circ} \mathrm{C}$. Reaction components and rest of the cyclic conditions were kept constant. However, annealing temperature of $58^{\circ} \mathrm{C}$ was selected to carry out mPCR on the basis of melting temperature of each primer of each serotype. At the selected annealing temperature of $58^{\circ} \mathrm{C}, \mathrm{mPCR}$ was carried out at $2 \mu \mathrm{l}$ of $25 \mathrm{mM}$ $\mathrm{MgCl}_{2}$ using $10 \mathrm{mM}$ dNTP. At a constant $\mathrm{MgCl}_{2}$ concentration, the influence of $2 \mu 1$ of $10 \mathrm{mM}$ dNTP was evaluated. A $0.2 \mu \mathrm{l}$ of LA Taq DNA polymerase was used in mPCR for all the serotypes. Different concentration (10 to 100 pmol) of each primer for each serotype was used and on the basis of band intensity, the final concentration (100 pmol) of each primer was selected for mPCR. After determining the optimum concentration of reaction mixture and annealing temperature of the primers, the cyclic condition, such as denaturation, annealing and extension time and also the number of cycles were adjusted for optimal performance. Based on the performance, the following cyclic conditions were selected for optimal performance: one cycle of $95^{\circ} \mathrm{C}$ for 15 min, 30 cycles of $95^{\circ} \mathrm{C}$ for $30 \mathrm{~s}, 58^{\circ} \mathrm{C}$ for $30 \mathrm{~s}, 72^{\circ} \mathrm{C}$ for $60 \mathrm{~s}$ and one cycle of $72^{\circ} \mathrm{C}$ for $10 \mathrm{~min}$.

\section{Agarose gel electrophoresis}

The PCR products were electrophoresed at $100 \mathrm{~V}$ for $30 \mathrm{~min}$ in TAE buffer on $2 \%$ agarose gel containing ethidium bromide $(0.6 \mathrm{mg} / \mathrm{ml})$. DNA molecular weight marker type $100 \mathrm{bp}$ DNA ladder was included to identify the size of the PCR products, using a GelMate 2000 (Toyobo) and UV-transilluminator (UVP Life Sciences).

\section{RESULTS AND DISCUSSION}

\section{Standardization of uniplex and multiplex RT-PCRs}

Uniplex and multiplex RT-PCRs were successfully developed and standardized using the extracted RNA of reference FMDV (Type A, $\mathrm{O}$ and Asia 1) following adjustment of the concentration of the viral RNA of each serotype, volume of reaction mixture and thermal profile. Initially, the set of primers for A, O, and Asia 1 typing were tested on cDNA from reference $\mathrm{A}, \mathrm{O}$ and Asia 1 serotypes, respectively. 


\section{M.A. Zinnah and others}

The A specific primers amplified a fragment of the correct size (376 bp) from A type tested. Similarly, the O primers amplified a product of 249 bp from O type and from Asia 1 type a PCR product of 537 bp was visible (Fig. 1). A multiplex mix that differentiated in one reaction among the three serotypes was composed by mixing the primers for A, O and Asia 1. The same specific PCR products were obtained with the separated primers: an amplicon of $376 \mathrm{bp}$ for A, an amplicon of $249 \mathrm{bp}$ for $\mathrm{O}$ and an amplicon of $537 \mathrm{bp}$ for Asia 1 (Fig. 2). No nonspecific bands were appeared on the gel due to cross reactivity among the three sets of type-specific primers used for the detection of three serotypes of FMDV in the MRT-PCR.

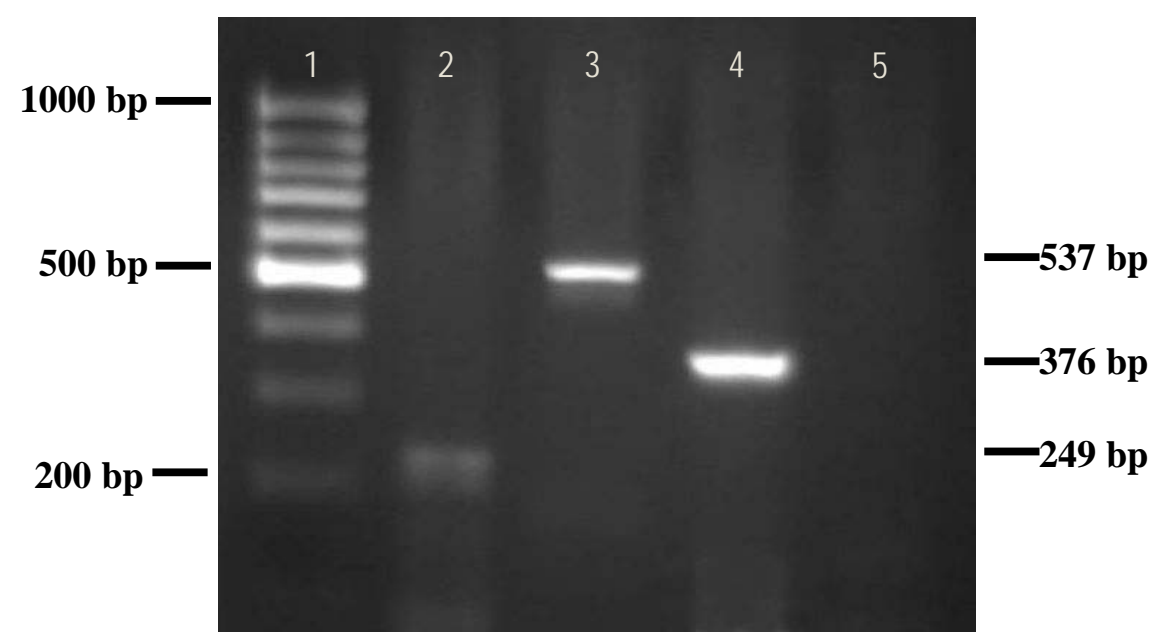

Fig. 1. Uniplex PCR products of three reference serotypes of FMDV after 2\% agarose gel electrophoresis. Lane 1 = DNA marker (100 bp), Lane 2 = Serotype O (249 bp), Lane $3=$ Serotype Asia 1 (537 bp), Lane $4=$ Serotype A (376 bp), Lane $5=$ Negative control (PBS).

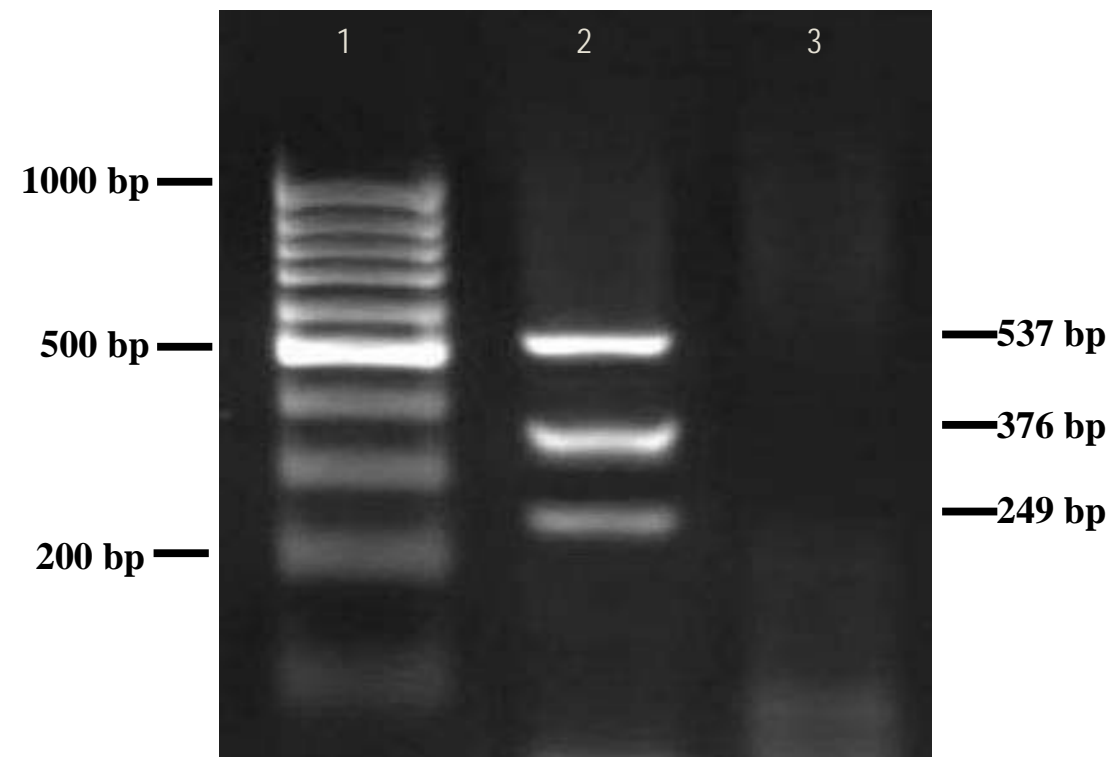

Fig. 2. Multiplex PCR products of three reference serotypes of FMDV after $2 \%$ agarose gel electrophoresis. Lane 1 = DNA marker (100 bp), Lane $2=$ Serotypes Asia 1 (537 bp), A (376 bp) and O (249 bp), Lane $3=$ Negative control (PBS). 


\section{Typing of FMDV in field samples by using MRT-PCR}

The mPCR was employed on 82 field samples of the years 2007 and 2008. Of the 82 field samples, 56 $(68.29 \%)$ were found positive for FMDV (Table 2). The mPCR produced a single band of $537 \mathrm{bp}$ and $249 \mathrm{bp}$ in the positive samples of Narshingdi and Rangur districts respectively of the year 2007 which indicated the presence of serotypes Asia 1 and O; however, two bands of $376 \mathrm{bp}$ and $249 \mathrm{bp}$ were found in 11 positive samples of Dhaka district of that year (Fig. 3). Since, the bands were of specific sizes, they indicated dual infection with serotypes A and O. Appearance of single band of $249 \mathrm{bp}$ after PCR and agarose gel electrophoresis in all positive samples of the year 2008 indicated the presence of serotype O. It is here to be mentioned that detection of FMDV was high $(100 \%)$ in vesicular fluid followed by tongue epithelium $(79.66 \%)$. Interestingly, only one sample $(6.67 \%)$ out of 15 tissue samples from interdigital space was found positive for FMDV by MRT-PCR.

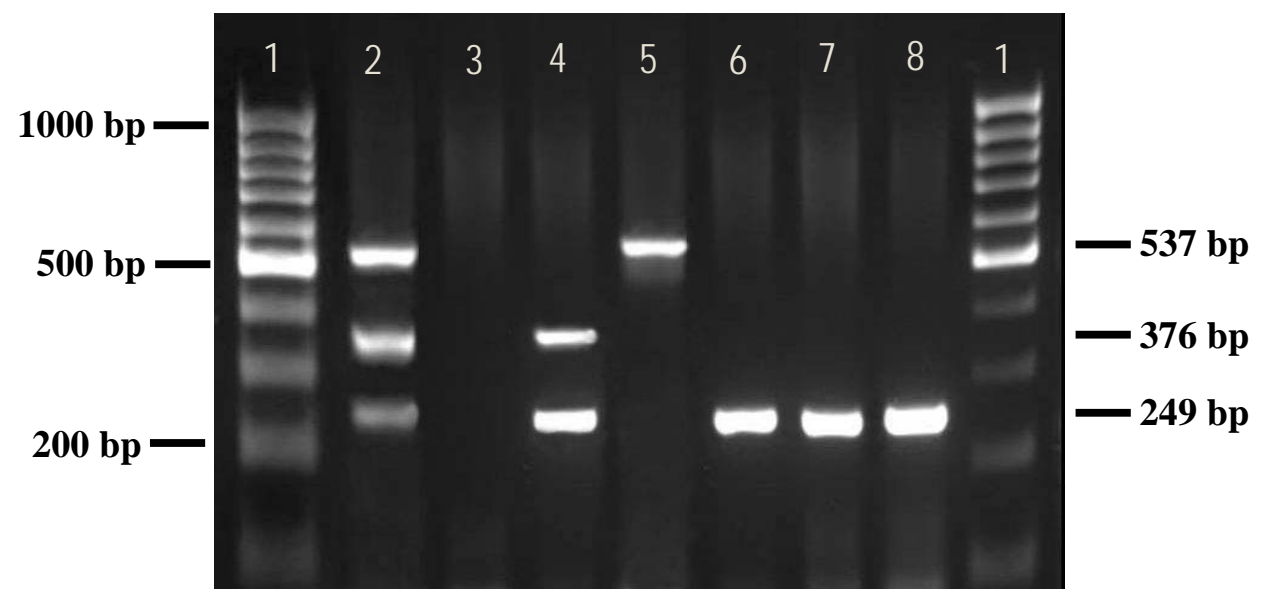

Fig. 3. Multiplex PCR products of field samples after $2 \%$ agarose gel electrophoresis. Lane $1=$ DNA marker (100 bp), Lane 2 = Positive controls (Serotypes Asia 1, A and O), Lane 3 = Negative control (PBS), Lane 4-8 = Field samples.

Table 2. Serotyping of FMDV using field samples by MRT-PCR

\begin{tabular}{|c|c|c|c|c|c|}
\hline \multirow[t]{2}{*}{ Place of sampling } & \multirow{2}{*}{$\begin{array}{l}\text { Type of } \\
\text { samples }\end{array}$} & \multirow{2}{*}{$\begin{array}{l}\text { No. of samples } \\
\text { tested }\end{array}$} & \multicolumn{2}{|c|}{ Positive in MRT-PCR } & \multirow[t]{2}{*}{ Serotype } \\
\hline & & & No. & $\%$ & \\
\hline \multirow[t]{3}{*}{ Dhaka } & VF & 3 & 3 & 100 & A \& O \\
\hline & $\mathrm{TE}$ & 8 & 8 & 100 & $A \& O$ \\
\hline & TIDS & 5 & 0 & 0 & - \\
\hline \multirow[t]{2}{*}{ Narshingdi } & TE & 8 & 8 & 100 & Asia 1 \\
\hline & TIDS & 5 & 0 & 0 & - \\
\hline \multirow[t]{2}{*}{ Rangpur } & $\mathrm{TE}$ & 8 & 8 & 100 & $\mathrm{O}$ \\
\hline & TIDS & 5 & 1 & 20 & $\mathrm{O}$ \\
\hline \multirow[t]{2}{*}{ Comilla } & $\mathrm{VF}$ & 3 & 3 & 100 & $\mathrm{O}$ \\
\hline & $\mathrm{TE}$ & 18 & 13 & 72.22 & $\mathrm{O}$ \\
\hline \multirow[t]{2}{*}{ Chittagong } & VF & 2 & 2 & 100 & $\mathrm{O}$ \\
\hline & $\mathrm{TE}$ & 17 & 10 & 58.82 & $\mathrm{O}$ \\
\hline Total & & 82 & 56 & 68.29 & \\
\hline
\end{tabular}

$\mathrm{VF}=$ Vesicular fluid; $\mathrm{TE}=$ Tongue epithelium; TIDS $=$ Tissue from interdigital space. 
Bangladesh has been considered as a FMD endemic country. Sometimes, outbreaks of FMD occurred in epidemic form here in Bangladesh. Serotype differentiation of FMDV has therefore become very essential for rapid diagnosis and serotyping and subsequently for the choice of emergency vaccines. Although, serotyping of FMDV is done using antigen capture ELISA as the routine method of choice (Ferris and Dawson, 1988), multiplex PCR (mPCR) is more sensitive and specific than ELISA for differentiating the serotypes of FMDV on clinical samples (Giridharan et al., 2005). This study demonstrates the differentiation of three serotypes (A, O, Asia 1) of FMDV by multiplex RT-PCR (MRT-PCR). The selection of appropriate primers is very important for success of any PCR. That is why, it is ideal to design the primers on the virus sequences native either to particular geographical area or at least country as a whole. The primers in this study were selected on the basis of published reports of Indian researchers (Giridharan et al., 2005) who designed the primers for four serotypes (A, $\mathrm{O}, \mathrm{C}$, Asia 1) of FMDV based on the virus sequences native to India and successfully developed mPCR. However, they observed that the limits of virus detection of $\mathrm{mPCR}$ varied between the serotypes and it was most sensitive on serotypes A and Asia 1 followed by O. It was considerably less sensitivity on serotype C under ethidium bromide stained gel visualization. Considering this fact, mPCR was developed in this study with a mixture of three serotypes (A, O and Asia 1), barring type $\mathrm{C}$. The primers were type specific and all the respective templates yielded a single band when the primers were used as multi-primer mixes.

A good amplification of all the targets had occurred at annealing temperature of $58^{\circ} \mathrm{C}$. However, the annealing temperature above $65^{\circ} \mathrm{C}$ did affect adversely the amplification efficiency. A fact behind this is that the primers used in MRT-PCR had a melting temperature within the range of 57-65 C. Henegariu et al. (1997) reported an inverse effect of annealing temperatures of above $60^{\circ} \mathrm{C}$ on amplification efficiency. It is not uncommon to have field samples containing a mixture of two or more serotypes as reported earlier (Hedger et al., 1972; Woodbury et al., 1995). Because of problems with multiple infected samples for laboratory diagnosis (Ferris et al., 1988), the ability of mPCR to detect all the three serotypes in a sample mix was tested. The mPCR could generate amplicons of expected sizes of serotypes A, O and Asia 1 efficiently when all the three serotypes were mixed at an equal ratio. However, there are reports of difficulties in the detection of $\mathrm{O}$ serotype in a mixture containing Asia 1 and O (Callens and De Clercq, 1997) and of serotype C in a mixture of serotypes A, O, C and Asia 1 (Giridharan et al., 2005).

From the results of typing of FMDV in field samples by using MRT-PCR, it can be seen that MRT-PCR worked more efficiently to detect mixed infection with serotypes A and O. However, it would be worthwhile to have a sample to be tested from cases of multiple infections with all the three serotypes. The detection rate of FMDV by MRT-PCR in different types of samples varied from $10 \%$ to $100 \%$. This variation might be due to the concentration of viruses in the samples. Giridharan et al. (2005) have also suggested that exposure of specimens to higher environmental temperatures, incorrect $\mathrm{pH}$ or putrefaction of the specimen might have contributed to virus degradation and lead to lowered virus or antigen concentrations from which sufficient intact RNA may or may not be extracted for the RT-PCR to function allowing amplification of the specific region of the viral genome (Reid et al., 1998; Marquardt et al., 1995). Besides, tissues of interdigital space of cattle are frequently exposed to soil, mud, naphthalene and oil of turpentine (used as fly repellent) and so on which possibly destroyed the FMDV to greater extent.

It may be concluded that the MRT-PCR standardized in this study could be used for detection and differentiation of FMDV serotypes using field samples. However, it would be ideal to determine the sequence of the PCR products obtained by this MRT-PCR for more confirmation and to evaluate this test on more FMD suspected samples from different parts of Bangladesh.

\section{ACKNOWLEDGEMENTS}

This work was financially supported by the Ministry of Science and Information \& Communication Technology, Government of the People's Republic of Bangladesh.

\section{REFERENCES}

1. Auge de Mello P, Honigman MH, Fernandes MV, Gomes I (1970). Further informations on the survival of modified foot-and-mouth disease virus in cattle. Bulletin of International Epizootics 73: 489 - 505.

2. Bachrach HL (1968). Foot-and-mouth disease. Annual Review of Microbiology 22: 201- 244. 
3. BBS (1999). Yearbook of Agricultural Statistics of Bangladesh. Bangladesh Bureau of Statistics. Ministry of Planning, Govt. of the Peoples Republic of Bangladesh.

4. Burrows R (1966). Studies on the carrier state cattle exposed to foot-and-mouth disease virus. Journal of Hygiene 64: 81 $-90$.

5. Callens M, De Clercq K (1997). Differentiation of the seven serotypes of foot-and-mouth disease virus by reverse transcriptase polymerase chain reaction. Journal of Virological Methods 67: 35 - 44.

6. Callens M, De Clercq K, Gruia M, Danes M (1998). Detection of foot-and-mouth disease by reverse transcription polymerase chain reaction and virus isolation in contact sheep without clinical signs of foot-and-mouth disease. Veterinary Questions 20: 37 - 40.

7. Fenner FJ, Gibbs PJ, Murphy FA, Rott R, Studdert MJ, White DO (1993). Veterinary Virology. 2nd ed. Academic Press, London, pp. 403 - 430.

8. Ferris NP, Dawson M (1988). Routine application of enzyme-linked immunosorbent assay in comparison with complement fixation for the diagnosis of foot-and-mouth and swine vesicular diseases. Veterinary Microbiology 16: 201 -209 .

9. Ferris NP, Powell H, Donaldson AI (1988). Use of pre-coated immunoplates and freeze-dried reagents for the diagnosis of foot-and-mouth disease and swine vesicular disease by enzyme-linked immunosorbent assay (ELISA). Journal of Virological Methods 19: 197 - 206.

10. Giridharan P, Hemadri D, Tosh C, Sanyal A, Bandyopadhyay SK (2005). Development and evaluation of multiplex PCR for differentiation of foot-and-mouth disease virus strains native to India. Journal of Virological Methods 126: 1 - 11.

11. Hamblin C, Armstrong RM, Hedger RS (1984). A rapid enzyme-linked immunosorbent assay for the detection of footand-mouth disease virus in epithelial tissues. Veterinary Microbiology 9: 435 - 443.

12. Hedger RS, Condy JB, Golding SM (1972). Infection of some species of African wildlife with foot-and-mouth disease virus. Journal of Comparative Pathology 82: 455-461.

13. Henegariu O, Heerema NA, Dlouhy SR, Vance GH, Vogt PH (1997). Multiplex PCR: critical parameters and step-bystep protocol. BioTechniques 23: 504-511.

14. Islam MA, Rahman MM, Adam KH, Marquardt O (2000). Epidemiological implications of the molecular characterization of foot-and-mouth disease virus isolated between 1996 and 2000 in Bangladesh. Virus Genes 23: 203 213.

15. Knowles NJ, Samuel AR (1998). Molecular techniques in foot-and-mouth disease epidemiology. IAEA-Proceedings 348: $185-201$

16. Marquardt O, Straub OC, Ahl R, Hass B (1995). Detection of foot-and-mouth disease virus in nasal swabs of asymptomatic cattle by RT-PCR within 24 hours. Journal of Virological Methods 53: 255 - 261.

17. OIE (2004). Principles of Veterinary Vaccine Production. In: Manual of Diagnostic Tests and Vaccines for Terrestrial Animals. Version adopted May 2006. Chapter 1.1.7.

18. OIE (2009). Foot and mouth disease. In: OIE Terrestrial Manual 2009. Version adopted May 2009. Chapter 2.1.5.

19. Reid SM, Firsyth MA, Hutchings GH, Ferris NP (1998). Comparison of reverse transcriptase polymerase chain reaction, enzymelinked immunosorbent assay and virus isolation for the routine diagnosis of foot-and-disease. Journal of Virological Methods 70: 213 - 217.

20. Rueckert RR (1996). Picornaviridae: the virus and their replication. In: Fields BN, Knipe DM, Howley PH (Eds.), Fields Virology, 3rd ed. Lippincott-Raven Publishers, Philadelphia, Pa. pp. 609-654.

21. Russel PH, Edington N (1985). Veterinary Viruses. The Burlington Press (Cambridge) Ltd. Foxton, Cambridge.

22. Sahan MS (1962). The virus of foot-and-mouth disease. Annals of New York Academy Science 101: $444-454$.

23. van Bekkum JG, Frenkel HS, Frederiks HHJ, Frenkel S (1959). Obsrevations on the carrier state of cattle expose. Tijdschr Diergeneesk 84: 1159 -1164.

24. Woodbury EL, Ilott MC, Brown CC, Salt JS (1995). Optimisation of an in situ hybridisation technique for the detection of foot-and-mouth disease virus in bovine tissues using the digoxigenin system. Journal of Virological Methods 51: 8993. 